\title{
ANALISIS MENGENAI MATERI MUATAN PERATURAN MAHKAMAH AGUNG NOMOR 2 TAHUN 2003 TENTANG PROSEDUR MEDIASI PENGADILAN
}

\author{
Oleh: \\ Rahardi Wasi Bintoro dan Tedi Sudrajat \\ Fakultas Hukum Universitas Jenderal Soedirman \\ E-mail: rahadiwasibintoro@yahoo.com dan t_Sudrajat@yahoo.com
}

\begin{abstract}
These days the solving of dispute by jurisdiction gets the critics from the practitioner and the jurist. The role and function of jurisdiction were assumed overloaded, wasting time, expressive, less responsive to the public interest, and also too formal and technical. There were various concepts that already offered to make the jurisdiction more simple, quick and light expenses. One of the concept which have been offered and now applying is the mediation institute in the civil the court system through PERMA No. 2 year 2003. The background of this regulation is because of the application of article 130 HIR is not effective. It changes the voluntary to the compulsory system by using the mediation institute. Now the party must used the mediation before entering the litigation.
\end{abstract}

Kata kunci: Jurisdiction, dispute and mediation.

\section{A. Pendahuluan}

Kecenderungan munculnya perselisihan di masyarakat sangatlah besar. Hal ini disebabkan antara lain adanya perbedaan tabiat dan kepentingan. Adapun yang dimaksud dengan kepentingan tersebut meliputi hak-hak dan kewajiban-kewajiban keperdataan yang diatur dalam hukum perdata materiil. ${ }^{1}$ Hukum perdata materiil terjelma dalam peraturan perundangundangan maupun ketentuan yang tidak tertulis yang merupakan pedoman bagi masyarakat tentang bagaimana orang selayaknya berbuat atau tidak berbuat di dalam bermasyarakat.

Dalam rangka melaksanakan hukum perdata materiil terutama dalam hal ada pelanggaran atau untuk mempertahankan berlangsungnya hukum perdata materiil dalam hal ada tuntutan hak diperlukan rangkaian peraturan hukum lain, yaitu hukum perdata formil dan hukum acara perdata. Hukum acara perdata adalah peraturan hukum yang

Retnowulan Sutantio dan Iskandar Oeripkartawinata, 2002, Hukum Acara Perdata Dalam Teori dan Praktek, Bandung: Mandar Maju, hlm 1. mengatur bagaimana caranya menjamin ditaatinya hukum perdata materiil dengan perantaraan kekuasaan negara. ${ }^{2}$ Ketentuan hukum acara perdata pada umumnya tidak membebani hak dan kewajiban seperti dalam hukum perdata materiil, tetapi melaksanakan dan mempertahankan atau menegakkan kaidah hukum perdata materiil yang ada, serta melidungi hak perseorangan.

Memasuki forum peradilan tidak ubahnya mengembara dan mengadu nasib di hutan belantara (adventure unto the unknow). Padahal masyarakat pencari keadilan membutuhkan proses penyelesaian yang cepat yang tidak formalitas atau informal prosedure and can be put into motion quicky. ${ }^{3}$ Dewasa ini penyelesaian sengketa melalui peradilan men-dapat kritik yang cukup tajam, baik dari praktisi maupun teoritisi hukum. Peran dan fungsi peradilan, dianggap mengalami beban yang

Sudikno Mertokusomo, 2002, Hukum Acara Perdata Indonesia, Yogyakarta: Liberty, hlm. 2.

3 Yahya Harahap, 1997, Beberapa Tinjauan Mengenai Sistem Peradilan dan Penyelesaian Sengketa, Sinar Grafika, hlm. 128. 
2 Jurnal Dinamika Hukum

Vol. 8 No. 1 Januari 2008

terlampau padat (everloaded), lamban dan buang waktu (waste of time), biaya mahal dan kurang tanggap terhadap kepentingan umum, serta terlampau formalistik dan terlampau teknis.

Pasal 130 HIR, 154 Rbg menyediakan sarana untuk menyelesaikan sengketa antara para pihak melalui perdamaian. Upaya perdamaian jauh lebih efektif dan efesien, antara lain disebabkan penyelesaian dilakukan informal, diselesaikan oleh para pihak sendiri, jangka waktu penyelesaian pendek, biaya ringan, tidak terkait pada aturan pembuktian, proses penyelesaian bersifat konfidesial, hubungan para pihak bersifat kooperatif, hasil yang dituju adalah sama-sama menang serta bebas dari emosi dan dendam.

Bertitik tolak dari Pasal 130 HIR, 154 Rbg dan untuk lebih memberdayakan dan mengefektifkan lembaga perdamaian, Mahkamah Agung memodifikasinya ke arah yang lebih memaksa (compulsory) melalui PERMA No. 2 Tahun 2003 tentang Prosedur Mediasi di Pengadilan. Oleh karena itu, para pihak yang berperkara tidak mempunyai pilihan lain selain harus lebih dahulu menempuh proses mediasi atau harus lebih dahulu diselesaikan melalui perdamaian dengan bantuan mediator. Sedemikian rupa sifat pemaksaan itu, sehingga penyelesaian melalui proses litigasi tidak mediator yang menyatakan proses mediasi gagal mencapai kesepakatan perdamaian. Hal ini ditegaskan dalam Pasal 12 ayat (2) PERMA No. 2 Tahun 2003.

\section{B. Perumusan Masalah}

1. Bagaimanakah materi muatan PERMA No. 2 Tahun 2003?

2. Apakah pelaksana lembaga mediasi sebagaimana diatur dalam PERMA No. 2 Tahun 2003 sesuai dengan asas hukum acara perdata?

3. Apakah PERMA No. 2 Tahun 2003 bertentangan dengan asas umum peraturan perundangan?

\section{Metode Penelitian}

Metode pendekatan yang digunakan dalam penelitian ini adalah yuridis normatif dengan spesifikasi penelitian berupa deskriptif análisis. Lokasi penelitian di Mahkamah Agung dengan sumber data berupa data sekunder yang berupa bahan hukum primer (berupa UUD 1945, HIR (S. 1941-44), RBg (S. 1927-227), UU No. 25 Tahun 2000 tentang Propenas Tahun 2000-2004, UU No. 4 Tahun 2004 tentang Kekuasaan Kehakiman, UU No. 14 Tahun 1985 jo UU No. 5 Tahun 2004 tentang Mahkamah Agung, UU No. 2 Tahun 1986 jo UU No. 8 Tahun 2004 tentang Peradilan Umum, UU No. 10 Tahun 2004 tentang Pembentukan Peraturan Perundangundangan, dan Surat Edaran Nomor 1 Tahun 2002 tentang Pengadilan Tingkat Pertama Menerapkan Lembaga Damai), dan bahan hukum sekunder (berupa buku literatur hukum, jurnal penelitian hukum, laporan penelitian hukum, laporan hukum media cetak maupun elektronik). Data yang diperoleh dianalisis dengan análisis kualitatif dan hasil penelitian disajikan secara deskriptif dalam bentuk uraian yang disusun secara sistematis

D. Pembahasan

1. Analisis Materi Muatan PERMA No 2 Tahun 2003 tentang Prosedur Mediasi di Pengadilan

Maksud dikeluarkanya PERMA No. 2

Tahun 2003 adalah untuk :

a. Mengurangi masalah penumpukan perkara;

b. Merupakan salah satu proses penyelesaian sengketa yang dianggap lebih cepat dan murah, serta dapat memberikan akses seluas mungkin kepada para pihak yang berperkara untuk memperoleh keadilan;

c. Memperkuat dan memaksimalkan fungsi lembaga pengadilan dalam penyelesaian sengketa di samping, proses ajudikatif;

d. Sebagai penyempurnaan lebih lanjut SEMA No. 1 Tahun 2002 tentang Pemberdayaan Pengadilan Tingkat Pertama Menerapkan Lembaga Damai (Eks Pasal 130 HIR /RBg);

e. Mendorong para pihak untuk menempuh proses perdamaian yang dapat diintesifkan dengan cara mengintegrasikan proses mediasi ke dalam prosedur berperkara di Pengadilan Negeri. 
Gagasan court-annexed ADR yang dikemukakan sejak 2001 kemudian pada 2003 direalisasikan dalam PERMA No. 02 Tahun 2003 tentang Prosedur Mediasi di Pengadilan. Penyelesaian sengketa lingkungan keperdataan yang melalui pengadilan terlebih dahulu wajib melalui proses mediasi di pengadilan, hal tersebut diatur dalam Pasal 2 Ayat (1) PERMA No. 2 Tahun 2003. Jika dilihat pengaturan tersebut dapat mempengaruhi sifat kesukarelaan (voluntariess) dan kebebasan para pihak, namun di sisi lainnya hal tersebut demi efektivitas Pasal 130 HIR maupun Pasal 154 RBg (mengenai kewajiban hakim untuk mendamaikan pihak yang bersengketa di awal proses gugatan). Sengketa lingkungan masuk dalam kategori sengketa publik (selain sengketa hak asasi manusia, perlindungan konsumen, pertanah-an dan perburuhan yang melibatkan ke-pentingan banyak buruh) dalam Pasal 1 Ayat (9) PERMA No. 2 Tahun 2003. Berikut ini mengenai perbedaan dan perkembangan mediasi berdasarkan bahan yang diperoleh Pusat Mediasi Nasional (PMN), yaitu:

Ada dua tipe mediasi, yaitu:

a. Out of Court Mediation

PMN (Pusat Mediasi Nasional) is proactively marketing mediation services to the private sector, the professions and particularly legal practitioners with an aim to encourage disputants to seek mediation as an effective Alternative Dispute Resolution (ADR). With limited marketing resources, PMN mediators have already begun to mediate cases such as on commercial and family disputes.

b. Curt-Annexed Mediation

To fully benefit the court-annexed mediation program throughout Indonesia, PMN aims to further assist the Supreme Court in providing mediation training for judges (there are 2.800 judges nationally) prioritizing in large cities such as Jakarta, Surabaya and Bandung, the implementation of this activity is fully dependent on donor support.

The current project funded by Indonesia Australia Legal Development Facility (IALDFAusAID) for judges mediation train-ing in
Bandung and Surabaya and Post Monitoring Program for South Jakarta, Bandung and Surabaya District Court. Post Monitoring comprises of (1) Co-mediation judge mediators with PMN trainers; (2) Refresh Course for judge mediator. There is additional program for South Jakarta District Court, a group of 20 PMN Listed Mediators serve pro-bono mediation service for court-annexed mediation cases. The activities started on December 2005 up to May 2006 for the first phase.

PMN is accredited by the Supreme Court of the Republic of Indonesia through the Decree of the Chief Justice of the Supreme Court (SK Ketua MA) No. KMA/044/SK/VIII 2004 dated July $6^{\text {th }}, 2004 .^{4}$

Mengenai latar belakang institusionalisasi mediasi di pengadilan, Penyusun PERMA tentang Prosedur Medias di Pengadilan mengemukakan bahwa institusionalisasi proses mediasi ke dalam sistem peradilan diharapkan dapat memperkuat dan memaksimalkan fungsi lembaga pengadilan dalam penyelesaian sengketa. Pemikiran tentang perlunya proses mediasi terkait dengan lembaga pengadilan pada dasarnya telah menjadi wacana di beberapa forum ilmiah. Di Indonesia pelembagaan proses mediasi yang terkait dengan lembaga pengadilan tersebut sebe-narnya tidak sulit untuk dilaksanakan karena Hukum Acara Perdata Indonesia yaitu Herziene Inlands Reglement (HIR) untuk wilayah Jawa dan Madura pasal 130/131 HIR dan Reglemen op de Buitengewesten $(\mathrm{RBg})$ untuk wilayah di luar Jawa dan Madura pasal 154 telah memberikan celah bagi terintegrasinya lembaga tersebut mengisyaratkan bahwa pada hari sidang yang ditunjuk, para pihak harus datang ke pengadilan dan adalah tugas Pengadilan Negeri, dengan perantaraan ketua-nya untuk mencoba memperdamaikan mereka yang bersengketa. Perlunya institusionalisasi pro-ses mediasi ke dalam sistem peradilan didasar-kan pada beberapa argumen. Pertama, hal itu merupakan salah satu upaya

4 Pusat Mediasi Nasional (PMN), Types of Medation (online) 6 Juli 2004, www.pmn.or.id (diakses 26 Februari 2006). 
membantu lembaga peradilan untuk mengurangi beban penumpukan perkara. Kedua, adalah penting bagi sistem hukum Indonesia untuk menyedia-kan akses seluas mungkin kepada para pihak yang bersengketa untuk mem-peroleh rasa keadilan karena salah satu fungsi dari sebuah sistem hukum adalah memfasilitasi terwujudnya keadilan. Tujuan ini dapat dicapai jika sistem hukum menye-diakan berbagai bentuk penyelesaian sengketa, termasuk mediasi. Ketiga, beberapa negara demokratis maju seperti Jepang, menginstitusionalisasikan mediasi sebagai proses penyelesaian sengketa di samping proses pengadilan yang bersifat memutus (adjudicative). Keempat, proses mediasi seringkali diasumsikan sebagai proses penyelesaian sengketa yang lebih efisien dan tidak memakan waktu dibandingkan proses memutus. Kelima, hukum acara yang berlaku di Indonesia mewajibkan para hakim pada sidang pertama untuk mendorong para pihak yang bersengketa agar menye-lesaikan sengketa melalui perundingan di antara mereka. Akan tetapi, karena fungsi hakim dan lembaga pengadilan sangat terbatas hanya mendorong para pihak, tetapi tidak secara langsung memfasilitasi, maka para pihak yang bersengketa belum secara optimal mengeksplorasi manfaat dari proses perundingan. Dalam upaya mencapai proses mediasi yang terintegrasi dengan sistem pengadilan yang baik menyempurnakan kegiatan penelitian yang tengah dilakukan, seminar tersebut di atas perlu dilakuka untuk mensosialisasikan adanya rancangan Peraturan Mahkamah Agung yang telah disusun atas kerjasama yang dilakukan Indonesian institute for Conflict Transformation (IICT) dan Publitbang MARI di atas di kalangan praktisi hakim, pengacara, serta akademisi dan untuk mendapt masukan dalam rangka revisi akhir rancangan Peraturan Mahkamah Agung tadi. Setelah Rancangan Peraturan Mahkamah Agung yang diseminarkan tersebut selesai dilakukan, maka tahap yang akan dilakukan selanjutnya dalam pene-litian ini adlah pelaksanaan uji coba untuk mengetahui seberapa efektif dan efisiennya peraturan Mahkamah Agung mengenai
"Prosedur Mediasi di Pengadilan" pada argumentasi tersebut di atas. ${ }^{5}$

PERMA No. 2 Tahun 2003 tentang Prosedur Mediasi di Pengadilan terdiri dari enam (6) Bab dan delapan belas (18) pasal. Bab I berisi tentang ketentuan umum, Bab II tentang tahap pra mediasi, Bab III tentang tahap mediasi, bab IV tentang tempat dan biaya, Bab $\mathrm{V}$ tentang lain-lain dan Bab VI tentang penutup.

Penguraian PERMA ini akan dilakukan sesuai proses yang telah diatur di dalam PERMA ini, yaitu: 1. pra mediasi, 2. mediasi, 3. pasca (pro) mediasi, 4. waktu, 5. Media-tor, 6. kuasa hukum, 7. isi kesepakatan, 8. tempat, 9. biaya, 10. hal-hal lain.

a. Pra Mediasi

Sesuai dengan pasal $130 \mathrm{HIR} / 154 \mathrm{Rbg}$ bahwa sebelum perkara diperiksa oleh majelis hakim tersebut. Dalam Pasal 2 ayat (1) disebut bahwa semua perkara perdata yang diajukan ke pengadilan tingkat pertama wajib untuk terlebih dahulu diselesaikan melalui perdamaian dengan bantuan mediator.

Pada sidang pertama yang dihadiri kedua belah pihak, hakim yang mengadilan perkara tersebut diwajibkan para pihak yang berperkara agar lebih dahulu menempuh mediasi (Pasal 3 ayat (1)). Selanjutnya, hakim tersebut wajib me-nunda proses persidangan perkara itu untuk memberi kesempatan kepada para pihak menempuh pross mediasi (Pasal 3 ayat (2)). Dengan adanya PERMA yang menentukan bahwa lamanya proses mediasi 30 hari (Pasal 5 ayat (1) dan (2)) atau 22 hari sejak pemilihan/ penetapan penunjukan mediator (Pasal 9 ayat (5)), maka hakim sebaiknya melakukan pe-nundaan sidang selama 32 hari, dengan ketentuan dapat dipercepat apabila tercapai kesepakatan secara dini atas laporan dari mediator ke hakim tersebut.

Pada sidang pertama, hakim juga diwajibkan untuk memberikan penjelasan

5 IICT, Penyusunan Rancangan PERMA tentang Prosedur Mediasi di Pengadilan: Sebuah Institutuinalisasi Mediasi ke dalam Sistem Peradilan di Indonesia, (on-line), 05 Agustus 2003, www.unej.ac.id (diakses 26 Februari 2006). 
para pihak tentang prosedur dan biaya mediasi (Pasal 3 ayat (3)). Kemudian dalam waktu paling lama satu hari kerja setelah sidang pertama, para pihak dan atau kuasa hukum mereka wajib berunding guna memilih mediator dari daftar mediator yang dimiliki oleh pengadilan atau mediator di luar daftar pengadilan (Pasal 4 ayat (1)). Jika dalam waktu satu hari kerja para pihak atau kuasa hukum mereka tidak dapat bersepakat tentang penggunaan mediator didalam atau diluar daftar pengadilan, para pengadilan tingkat pertama (Pasal 4 ayat (2)). Apabila para pihak tetap juga tidak dapat bersepakat dalam menentu-kan seorang mediator dari daftar yang tersedia, maka ketua majelis berwenang untuk menunjuk seorang mediator dari daftar mediator dengan penetapan (Pasal 4 dan Pasal 3). Di dalam PERMA ini juga ditegaskan bahwa para pihak wajib mengikuti prosedur penyelesaian seng-keta melalui mediasi yang telah diatur didalam PERMA ini (Pasal 7).

b. Mediasi

Pada tahap ini, dinyatakan bahwa dalam waktu paling lama tujuh hari kerja setelah pemilihan atau penunjukan mediator, para pihak wajib menyerahkan fotocopy dokumen yang memuat duduk perkara, fotocopy surat-surat yang diperlukan dan hal terkait dengan sengeta kepada mediator (Pasal 8).

Mediator wajib menentukan jadwal pertemuan untuk penyelesaian proses mediasi (Pasal 9 ayat (1)). Apabila dianggap perlu, mediator dapat melakukan kaukus (Pasal 9 ayat (3)). Atas persetujuan para pihak atau kuasa hukum, mediator dapat mengundang seorang untuk lebih ahli dalam bidang tertentu untuk memberikan penjelasan atau pe-netapan menunjukkan mediator (Pasal 10 ayat (1)). Jika mediasi menghasilkan kesepakatan, para pihak yang dicapai dan ditandatangani oleh para pihak (lihat Pasal 11 dan (1)). Proses mediasi pada asasnya tidak bersifat terbuka untuk umum, kecuali para pihak menghendaki lain. Proses mediasi untuk sengketa publik terbuka untuk umum (pasal 14 ayat (1) dan (2)).

\section{c. Pasca (post) Mediasi}

Untuk mediasi yang menggunakan mediator diluar daftar mediator untuk dimiliki pengadilan, dinyatakan bahwa setelah waktu 30 (tiga puluh) hari kerja terpenuhi para pihak wajib mengharap kembali pada hakim pada sidang yang ditentukan (Pasal 5 ayat (2)). Pada persidangan tersebut jika para pihak mencapai kesepakatan, mereka dapat meminta penetapan dengan suatu akta perdamaian (Pasal 5 ayat (2)). Pada persidangan tersebut jika para pihak mencapai kesepakatan, mereka dapat meminta penetapan dengan suatu akta perdamaian (Pasal 5 ayat (3)). Jika para pihak berhasil mencapai kesepatan namun tidak dimintakan penetapannya sebagai suatu akta perdamaian, pihak penggugat wajib menyatakan pen-cabutan gugatannya (Pasal 5 ayat (4)).

Dalam hal mediasi dengan mempergunakan mediator yang terdaftar di pengadilan, maka jika gagal mencapai sepakat; para pihak wajib menghadap kembali pada hakim pada hari sidang yang ditentukan untuk memberitahukan kegagalan tersebut kepada hakim (Pasal 11 ayat (4)). Jika dalam waktu seperti yang ditetapkan dalam Pasal 9 ayat (5) mediasi tidak menghasilkan kesepakat-an, mediator wajib menyatakan secara tertulis bahwa proses mediasi telah gagal dan memberitahukan kegagalan kepada hakim (Pasal 12 ayat (1)).

Pasal 12 ayat (1) ini hanya menyebutkan jika gagal mencapai sepakat sedang jika tercapai kesepakatan tidak disebut, lepas dari itu, biak tercapai maupun tidak kesepatan, para pihak tetap harus hadir pada persidangan yang telah ditetapkan hakim, dan menyampaikan segala sesuatunya tentang mediasi kepada hakim tersebut. Seterusnya hakim dapat mengukuhkn kesepakatan dari mediator itu, hakim melanjutkan pemeriksaan perkara sesuai ketentuan Hukum Acara yang berlaku (Pasal 12 ayat (2)). Ada hal yang sebaiknya harus 
diatur di dalam pasal ini, yaitu apabila tercapai kesepatan dini dan dicapai dalam satu kali sidang mediasi saja, mediator melapor ke hakim, guna penetapan sidang yang lebih cepat untuk mendapat pengukuhan dari hakim tersebut.

\section{d. Waktu}

Proses mediasi yang menggunakan mediator di luar daftar mediator yang di-miliki oleh pengadilan berlangsung paling lama 30 hari kerja (Pasal 5 ayat (1)). Jika menggunakan mediator yang terdaftar di pengadilan, mediasi dilakukan selama 20 hari kerja sejak penetapan penunjukan mediator baik menghasilkan atau tidak menghasilkan kesepakatan (Pasal 9 ayat (5)).

e. Mediator

Dalam melaksanakan fungsinya, mediator wajib menaati kode etika mediator (Pasal 2 ayat (2)). Juga tidak diperbolehkan seorang mediator merangkap sebagai hakim yang memeriksa dan mengadili perkara tersebut. Ketentuan ini disimpulkan dari pasal yang menyatakan bahwa hakim memeriksa suatu perkara, baik sebagai ketua majelis atau anggota mejelis, dilarang bertindak sebagai mediator bagi perkara yang bersangkutan (Pasal 4 ayat (4)).

Mediator pada setiap pengadilan dapat berasal dari kalangan hakim dan buka nhakim yang memiliki sertifikat sebagai mediator (Pasal 6 ayat (1)). Ketentuan pasal ini agak kurang sinkron dengan Pasal 5 ayat (1), dimana pada pasal tersebut diatur tentang proses mediasi yang menggunakan mediator di luar daftar mediator yang dimiliki pengadilan. Akan timbul suatu pertanyaan siapa yang berhak untuk mengeluarkan sertifikat sebagai mediator bagi mediator yang berasal dari kalangan bukam hakim. Sebaiknya mediator yang bukan hakim diakomodir di lembaga mediasi yang berada di luar pengadilan, agar para pihak tetap mempunyai kebebasan untuk memilih mediator yang berasal dari hakim. Setiap pengadilan memiliki sekurang-kurangnya dua orang mediator (pasal 6 ayat 2) dan setiap pengadilan wajib memiliki daftar mediator riwayat hidup dan pengalaman kerja mediator mengevaluasi daftar tersebut setiap tahun (Pasal 6 ayat (3)).

Tanggung jawab mediator juga diatur dalam PERMA ini dengan menyatakan bahwa mediator wajib mendorong para pihak untuk menelusuri dan menggali kepentingan mereka dan mencari berbagai pilihan penyelesaian yang terbaik bagi para pihak (Pasal 9 ayat (4)). Ketentuan ini agar tercapai kesepakatan yang bersifat win-win solution. Karena proses mediasi pada asasnya bersifat rahasia dan terpisahkan dari litigasi, setiap mediator tidak dapat diminta menjadi saksi dalam proses persidangan perkara yang bersangkutan (Pasal 13 ayat (3)).

\section{f. Kuasa Hukum}

PERMA ini hanya mengatur 2 (dua) ketentuan tentang kuasa hukum yaitu :

a. Dalam hal para pihak memberikan kuasa kepada kuasa hukum, setiap keputusan yang diambil kuasa hukum wajib memperoleh persetujuan ter-tulis dari para pihak (Pasal 3 ayat (4)).

b. Dalam proses mediasi para pihak dapat didampingi oleh kuasa hukum-nya (Pasal 9 ayat (2)).

Pada prinsipnya dalam proses mediasi harus dihadiri oleh para pihak prinsipal, namun kehadiran kuasa hukum dalam proses mediasi tidaklah dilarang, dalam arti bahwa kuasa hukumnya haruslah bertindak pasif saja.

Berkaitan dengan surat kuasa yang dimiliki oleh kuasa hukum, dapat diasumsikan bahwa yang berhak memeriksa surat kuasa tersebut adalah hakim yang mengadili perkara tersebut, hal ini dapat diasumsikan dari letak ketentuan Pasal 3 dan (4) yang berada pada Bab II tentang tahap Pra Mediasi.

\section{g. Isi Kesepatan}

Kesepakatan dibuat secara tertulis (Pasal 11 ayat (1)) dan wajib memuat klausula pencabutan perkara atau pernyataan perkara telah selesai (Pasal 11 ayat (2)). Pasal ini kurang tepat, se-harusnya 
tidak perlu dilakukan pen-cabutan perkara cukup dilakukan per-mohonan kepada hakim untuk pengukuh-an kesepakatan (acte van dading). Tetapi khusus untuk perkara perceraian yang telah mencapai kesepakatan haruslah dicantumkan klausula pencabutan perkara, dan tidak bisa dikukuhkan oleh hakim yang bersangkutan.

Mediator wajib memberiksa materi kesepakatan untuk menghindari adanya kesepakatan yang bertentangan dengan hukum sebelum para pihak menandatanganinya (Pasal 11 ayat (3)). Dari ketentuan ini dapat disimpulkan bahwa mesti ada kesepakatan dari para pihak terlebih dahulu, yang dibuktikan dengan tanda tangan, dan kesepakatan ini haruslah tidak bertentangan dengan hukum dan ketertiban umum.

Namun disamping itu juga perlu diatur tentang bahwa kesepatan tersebut haruslah berupa penyelesaian perkara, karena bisa saja ada kesepatan tapi tidak menyelesaikan perkara, misalnya para pihak sepakat untuk menghentikan perkara untuk sementara waktu. Kesepatan tersebut tidak mengenai materi perkara dan hal demikian tidaklah menyelesaikan perkara, dan tentunya kesepakatan tersebut tidak dapat di-kukuhkan oleh pengadilan.

h. Tempat

Mediasi dapat diselenggarakan di salah satu ruang pengadilan tingkat pertama atau tempat lain yang disepakati oleh para pihak (Pasal 15 ayat (1)). Sebaiknya tempat proses mediasi dilakukan di gedung pengadilan, karena kalau berada di luar gedung pengadilan secara psikologi tidak baik kepada hakim, kecuali mediator yang bukan hakim. Namun akan muncul permasalahan berkaitan dengan ruangan medasi yang kurang memadai dan tidak cukup untuk konfrense mediasi.

i. Biaya

Semua biaya jasa seorang ahli atau lebih ditanggung para pihak berdasarkan kesepatan (Pasal 10 ayat (2)). Penyelenggaraan mediasi disalah satu ruang pengadil- an tingkat pertama tidak dikenakan biaya (Pasal 15 ayat (2)). Akan tetapi jika para pihak memilih penyelenggaraan mediasi di tempat lain, pembiayaan dibebankan kepada para pihak berdasarkan kesepatan (Pasal 15 ayat (3)).

Penggunaan mediator hakim tidak dipungut biaya (Pasal 15 ayt (4)). Biaya mediator bukan hakim ditanggung oleh para pihak berdasarkan kesepakatan kecuali terhadap pihak yang tidak mampu (Pasal 15 ayat (4)).

Ketentuan di atas adalah merupakan konsekuensi dari masuknya mediator yang bukan hakim ke lembaga pengdilan. Pengawasan, tempat/ruangan, gaji/honor para mediator yang bukan hakim, apabila terjadi masalah antara mediator non hakim dengan para pihak, siapa yang menyelesaikan.

j. Hal-hal lain

Jika para pihak gagal dalam mencapai kesepatan, pernyataan dan pengakuan para pihak dalam proses mediasi tidak dapat digunakan sebagai alat bukti dalam proses persidangan perkaran yang bersangkutan dan perkara lainnya (Pasal 13 ayat (1)). Fotocopy dokumen dan notulen atau catatan mediator wajib dimusnahkan (Pasal 13 ayat (2)). Ketentuan pasal ini dimaksudkan untuk menjaga kerahasiaan proses mediasi.

2. Kesesuaian antara PERMA No. 2 Tahun 2003 dengan Asas Hukum Acara Perdata

Untuk memulihkan hak seseorang yang dilanggar, dilakukan upaya hukum dengan pengajuan gugatan (ada tuntutan hak) melalui pengadilan. Tugas pengadilan, dalam hal ini adalah hakim, yaitu untuk memeriksa, memutuskan, dan mengadili perkara perdata. Sebelum diatur lembaga mediasi dalam PERMA No. 2 Tahun 2003 tentang mediasi di pengadilan, berdasar pasal $130 \mathrm{HIR} /$ Pasal $154 \mathrm{Rbg}$ dalam sidang pertama hakim akan mencoba mendamaikan para pihak terlebih dahulu. Hal ini dilakukan oleh hakim dalam bentuk anjuran kepada para pihak untuk berdamai dan lebih bersifat formalistis. Hakim dalam setiap pemeriksaan persidangan selalu memulai 
dengan kalimat: "apakah para pihak telah mengupayakan perdamaian atau belum dan bagaimana hasilnya?

Upaya perdamaian yang digariskan Pasal 130 jo Pasal 131 HIR merupakan suatu kewajiban. Bagi hakim yang mengabaikan tahap ini dan langsung memasuki proses persidangannya pada tahap pemeriksaan sengketa para pihak, dianggap telah melanggar tata tertib beracara, sehingga proses pemeriksaan dikualifikasikan undue proccess. Hal ini mengakibatkan pemerik-saan tidak sah dan harus dinyatakan batal demi hukum. ${ }^{6}$ Upaya perdamaian harus dicantumkan dalam putusan hakim nantinya.

Memperhatikan keadaan yang demikian, dimana proses perdamaian lebih bersifat formalistis belaka, maka Mahkamah Agung terpanggil untuk lebih memperdayakan para hakim untuk menyelesaikan perkara dengan perdamaian sebagaimana digariskan pasal 130 HIR, melalui mekanisme integrasi mediasi dalam sistem peradilan. Kemudian lahirkan PERMA No. 2 Tahun 2003 tentang Mediasi di Pengadilan Negeri.

Proses mediasi berdasarkan PERMA No. 2 Tahun 2003 secara mutlak wajib ditempuh. Dengan demikian semua perkara wajib lebih dahulu diselesaikan melalui mediasi, sebagaimana digariskan Pasal 2 ayat (1) PERMA No. 2 Tahun 2003, bahwa setiap penyelesaian perkaran yang diajukan ke pengadilan, wajib lebih dahulu menempuh proses mediasi. Sedangkan menurut Pasal 12 ayat (2), pengadilan baru boleh memeriksa perkara melalui proses hukum acara perdata biasa, apabila proses mediasi gagal menghasilkan kesepatan. Jadi, se-belum ada pernyataan secara tertulis dari mediator yang menyatakan proses mediasi gagal mencapai kesepatan perdamaian, penyelesaian melalui proses litigasi tidak boleh dilakukan. Proses mediasi sendiri dilakukan melalui pertemuan dan perundingan para pihak yang berperkara dengan dibantu langsung oleh mediator secara aktif, mulai dari awal sampai akhir proses. Perlu ditegaskan disini, bahwa

6 Yahya Harahap, Op.cit hlm. 240 yang memaksa penyelesaian perkara melalui mediasi adalah hakim.

Tentu saja hal tersebut berbeda dengan proses perdamaian yang diatur dalam Pasal 130 HIR yang menggunakan istilah "hakim mencoba mendamaikan para pihak yang berperkara". Dimana dalam praktiknya hakim terbatas pada tindakan untuk mengajukan dan menyuruh para pihak untuk mengupayakan sendiri perdamaian tanpa keterlibatan hakim dalam pertemuan dan perundingan yang dilakukan para pihak yang berperkara.

Sebenarnya sejak semula HIR maupun Rbg mengenal dan menghendaki penyelesai-an sengketa melalui cara damai. Hal ini tampak pada ketentuan pasal 130 ayat (1) HIR yang merumuskan:

"Jika pada hari yang ditentukan itu kedua belah pihak datang, maka pengadilan negeri dengan pertolongan ketua mencoba akan memperdamaikan mereka"7 Selanjutnya ayat (2) merumuskan: jika perdamaian yang demikian dapat dicapai, pada waktu bersidang, diperbuat sebuah surat (akta) tentang itu, dalam mana kedua belah pihak dihukum akan menaati perjanjian yang diper-buat itu, surat mana akan berkekuatan dan akan dijalankan sebagai putusan yang biasa"

Bertitik tolak dari ketentuan tersebut, sistem yang diatur dalam hukum acara dalam penyelesaian perkara yang diajukan kepada pengadilan negeri, menunjukkan bahwa jauh hari sebelum sistem ADR (Alternative Dispute Resolution) dikenal pada era sekarang, telah dipancangkan landasan yang menuntut dan mengarahkan penyelesaian sengketa melalui perdamaian. Bentuk penyelesaian yang digariskan pasal 130 HIR merupakan kombinasi antara system mediasi dan konsiliasi dengan court connected system, sehingga dapat dirangkai menjadi court connected mediation atau consiliation. Dalam sistem ini, para pihak penyelesai akan sendiri lebih dahulu kesepakatan tanpa campur tangan hakim. Selanjutnya, kesepakatan perdamaian tersebut di-

\footnotetext{
R Soesilo, 1985, RIB/HIR dengan Penjelasannya, Bogor: Politeia, hlm. 88

8 Ibid
} 
mohonkan kepada hakim untuk dituangkan dalam bentuk akta perdamaian.

Dengan demikian tanpak bahwa intervensi hakim dalam pencapaian suatu perdamaian bagi para pihak yang berperkaran adalah sangat kecil. Intervensi hakim diwujudkan dalam suatu anjuran bagi para pihak untuk melakukan upaya per-damaian dan pembuatan akta perdamaian yang dijatuhkan sebagai putusan pengadilan yang berisi amar menghukum para pihak untuk menaati dan memenuhi isi perjanjian. Sementara proses pencapain perdamaian yang merupakan penerapan konsep win-win solution diserahkan sepenuhnya kepada para pihak.

Ketentuan Pasal 2 ayat (1) PERMA No. 2 Tahun 2003, menggariskan bahwa setiap penyelesaian perkara yang diajukan ke pengadilan, wajib lebih dahulu menempuh proses mediasi. Hal ini ditegaskan lagi dalam pasal 12 ayat (2), pengadilan baru boleh memeriksa perkara melalui proses hukum acara perdata biasa, apabila proses mediasi gagal menghasilkan kesepakatan. Jadi, sebelum ada pernyataan secara tertulis dari mediator yang menyatakan proses mediasi gagal mencapai kesepakatan perdamaian, penyelesaian melaui proses litigasi tidak boleh dilakukan.

Berdasarkan uraian tersebut diatas dapat dideskripsikan bahwa sebagai suatu konsep penyelesaian sengketa dalam proses integrasi mediasi dalam sistem peradilan adalah langsung sejak awal sampai akhir proses mediasi. Sebaliknya keterlibatan hakim dalam proses perdamaian berdasarkan psal $130 \mathrm{HIR} /$ pasal 154 Rbg tidak langsung secara aktif, proses perdamaian diajukan hanya sekedar formalitas dalam bentuk anjuran untuk ber-damai yang diajukan oleh hakim kepada para pihak dalam setiap persidangan, mengingat bahwa perdamaian dapat dilakukan setiap saat selama proses persidangan. Dalam hal ini, hakim bersifat pasif karena menyerahkan se-penuhnya pertemuan dan perundingan per-damaian kepada para pihak.

Kepasifan hakim dalam pelaksanaan perdamaian berdasarkan Pasal 130 mendasarkan pada asas hukum acara perdata bahwa hakim bersifat pasif, menurut Sudikno Mertokusumo, hakim di dalam memeriksa perkara perdata bersikap pasif mengandung arti bahwa ruang lingkup atua luas pokok sengketa yang diajukan kepada hakim untuk diperiksa dalam asasnya ditentukan oleh pada pihak yang berperkara dan buka oleh Hakim. ${ }^{9}$ Dengan pengertian lain, para pihaklah yang menentukan luas pokok perkara yang disengketakan dan para pihaklah yang menentukan apakah dirinya akan mengajukan upaya hukum atau tidak. Hakim wajib mengadili seluruh gugatan dan dilarang menjatuhkan putusan atas perkara yang tidk dituntut atau mengabulkan lebih dari yang dituntut (Pasal 178 ayat (2) dan (3) HIR, 189 ayat (2) dan (3) Rbg). Hakim yang membantu para pencari keadilan dan berusaha mengatasi segala hambatan dan rintangan untuk dapat tercapainya peradilan (Pasal 5 ayat (2) UU No. 4 Tahun 2004). Hakim harus aktif memimpin pemeriksaan perkaran dan harus berusaha sekeras-kerasnya mengatasi segala hambatan dan rintangan untuk dapat tercapainya peradilan.

Berdasarkan uraian tersebut maka da-pat dideskripsikan bahwa mediasi sebagaimana diatur didalam PERMA No. 2 Tahun 2003 tidak satu ruh dengan HIR, khususnya Pasal 130 HIR/Pasal 154 Rbg. Padahal PERMA sendiri dimaksudkan untuk melaksanakan lebih lanjut tentang medasi di pengadilan sebagaimana diatur dalam HIR maupun Rbg. Upaya hakim yang mewajibkan para pihak untuk lebih dahulu menempuh tahap mediasi sebagaimana diatur dalam PERMA NO. 2 Tahun 2003 bertentangan dengan asas hakim bersifat pasif dalam HIR, karena segala pokok sengketa, luas ruang lingkupnya, pengajuan upaya hukumnya seluruhnya diserahkan kepada para pihak. Perdamaian merupakan suatu bentuk uapaya hukum untuk menyelesaikan satu perkaran dan oleh karenanya menjadi hak sepenuhnya bagi pihak untuk menentukan apakah sengketa yang terjadi akan diselesaikan melalui taha litigasi atau non litigasi. Selain dalam persidangan pertama, para pihak dalam sidang berikutnya

\footnotetext{
Sudikno Mertokusumo, op.cit, hlm. 12
} 
juga tetap dimungkinkan untuk berdamai. Kepasifan hakim ini mengandung pengertian, bahwa selain luas pokok sengketa ditentukan para pihak, para pihak juga boleh sewaktuwaktu menyelesaikan perkaranya baik memalui pencabutan gugatan maupun dengan perdamaian.

Seperti diketahui untuk lebih mengefektifkan lembaga perdamaian berdasar PERMA No. 2 Tahun 2003, pada peradilan tingkat per-tama pada pihak wajib memalui masa mediasi yang waktunya ditentukan oleh peraturan ter-sebut yaitu 31 hari penyelesaian damai melaui medator di luar pengadilan, dan waktu 23 hari melaui mediator dalam lingkungan pengadilan negeri. Berdasar pada suatu penelitian sebelumnya yang telah dilakukan di wilayah Eks Karesidenan Banyumas, yang telah melakukan penelitian terhadap para pengcara, hakim meupun tenaga administrator pengadilan serta data nomatif yang diperoleh dari 4 Pengadilan Negeri yaitu Purbalingga, Cilacap, Banjarnegara, dan Purwokerto, ternyata upaya perdamaian melaui mediasi jumlahnya sangat kecil dalam arti tidak signifikan dengan keberadaan dan aktivitas lembaga mediasi, walaupun ada data 1 atau 2 perkaran yang berhasil didamaikan melalui mediasi. ${ }^{10}$

Berdasarkan hal tersebut, lembaga mediasi tidak efektif sebagai upaya hukum yang diwajibkan oleh hakim untuk penyelesaian suatu sengketa melalui perdamaian. Oleh karena sifatnya wajib bagi setiap perkaran perdata untuk menempuh yapaya mediasi, maka setiap perkara akan mengalami kemunduran pemeriksaan persidangan. Oleh karena itu, sebenarnya waktu wjib yang disediakan untuk menempuh uapaya mediasi justru memperlama proses pemeriksaan di persidangan tingkat pertama. Hal ini tentu saja tidak sesuai dengan asa "Peradilan sederhana, cepat dan biaya ringan" yang diemban suatu sistem peradilan.

10 Pramono Suko Legowo dan Rahadi Wasi Bintoro, 2007, Efektivitas Sistem Peradilan Sederhana Cepat dan Biaya Ringan, Penelitian dengan sumber dana anggaran Rutin Unsoed, hlm. 54.
3. Kesesuaian antara PERMA No. 2 Tahun 2003 dengan Asas Umum Peraturan Perundangan

Perundang-undangan dalam bahasa Belanda dikenal dengan istilah wet, wetgeving, wettelijke regels atau wetteljke regiling (en). Adapun yang dimaksud dengan "peraturan negara" adalah peraturan-peraturan tertulis yang diterbitkan oleh instansi resmi, baik dalam pengertian lembaga atau pejabat tertentu. ${ }^{11}$ Sedangkan yang dimaksud dengan peraturan perundang-undangan adalah per-aturan mengenai tata cara pembuatan peraturan negara. $^{12}$

Dalam konsep negara hukum yang demokratis keberadaan peraturan perundangundangan dimaksud-kan untuk membatasi kekuasaan pemerintah. Peraturan perundangundangan merupakan salah satu sarana yang strategis dalam mengimplementasikan ide negara hukum. Untuk itu dalam pembentukannya harus didasarkan pada be-berapa asas. Menurut Van der Vlies sebagai-mana dikutip oleh A. Hamid S. Attamimi membedakan 2 (dua) kategori asas-asas pembentukan peraturan perundang-undangan yang patut (Beginselen van behoorlijk regilgeving), yaitu asas formal dan asa material.

\section{Asas-asas formal meliputi:}

a. Asas tujuan jelas (Het beginsel van duideijke doelstelling)

b. Asas lembaga yang tepat (Het beginsel van het juiste orgaan)

c. Asas perlunya pengaturan (Het noodzakelijkheid beginsel)

d. Asas dapat dilaksanakan (Het beginsel van uitvoerbaarheid)

e. Asas konsensus (Het beginsel van de concensus)

Asas-asas material meliputi:

a. Asas kejelasan teminologi dan sistematika (het beginsel van de uidelijke terminologie en duidelijke systematiek)

\footnotetext{
11 H. Rosjidi Ranggawidjaja, 1998, Pengantar Ilmu Perundang-Undangan Indonesia. CV. Mandar Maju, Bandung, hlm.. 16.

12 Loc.cit.
} 
b. Asas bahwa peraturan perundang undangan mudah dikenali (Het beginsel van den kenbaarheid)

c. Asas persamaan (Het rechts gelijkheids beginsel)

d. Asas kepastian hukum (Het rechtszekerheids beginsel)

e. Asas pelaksanaan hukum sesuai dengan keadaan individual (Het beginsel van de individuele rechtsbedeling)

Mengenai keberadaan PERMA, maka menurut Pasal 7 ayat 4 UU No. 10 Tahun 2004 disebutkan bahwa jenis peraturan perundangundangan selain sebgaimana yang dimaksud pada Pasal 7 ayat (1), diakui keberadaannya dan mempunyai kekuatan hukum mengingat sepanjang diperintah oleh peraturan perundang-undangan yang lebih tinggi.

PERMA merupakan salah satu bentuk peraturan pelaksa-naan dari undang-undangan atau biasa disebut dengan subordinate legislations yang merupakan peraturan yang didelegasikan oleh undang-undang (delegated legislations). PERMA masuk dalam kategosi allgemeene ver-vindende voorschrffen atau peraturan yang mengikat untuk umum. Dalam bahasa Belanda, bentuk peraturan yang ditetapkan oleh para administrator sebagai pelaksana fungsi-fungsi administrasi negara dalam rangka melaksanakan ketentuan undangundang disebut juga dengan istilah besluit van allgemene strekking atau keputusan yang berisi ketentuan yang berlaku umum. ${ }^{13}$

Kaitannya dengan asas umum perundangundangan dapat diketahui bahwa berdasarkan konsiderans PERMA No. 2 Tahun 2003 butir d, keberadaan PERMA dimaksudkan untuk menyempurnakan lebih lanjut SEMA No. 1 Tahun 2002 tentang Pemberdayaan Pengadilan Tingkat Pertama Menerapkan Lembaga Damai (Eks Pasal $130 \mathrm{HIR} / 154$ RBg). Sehingga dapat dideskripsikan bahwa PERMA ini dibentuk untuk merubah paradigma yang selama ini yang diterapkan dalam melaksanakan HIR khususnya pasal 130. Namun permasalahannya adalah

13 Jimly Asshiddiqie. 2006. Pengantar Ilmu Hukum Tata Negara. Kekretariat dan Kepaniteraan Mahkamah Konstitusi. Jakarta. Hlm.. 226.
PERMA tersebut secara hierarkis berada di bawah dari HIR sehingga tidak sesuai sebagai penyempurnaan keberadaan dari HIR. Dalam hal ini tidak sesuai sebagai penyempurnaan keberadaan dari HIR. Dalam hal ini tidak berlaku asas "Lex Specialis Derogat Legi Generali".

Menyikapi hal di atas, maka PERMA No. 2 Tahun 2003 tidak sesuai dengan asas peraturan perundang-undangan karena bertentangan dengan peraturan perundang-undangan. Hal ini dikarenakan PERMA hanya merupakan peraturan pelaksana dari undang-undang.

\section{E. Penutup}

1. Simpulan

a. Secara filosofis, maksud dibentuknya PERMA adalah untu:

1) Mengurangi masalah penumpukan perkara;

2) Merupakan salah satu proses penyelesaian sengketa yang dianggap lebih cepat dan murah, serta dapat memberikan akses seluas mungkin kepada para pihak yang bersengketa untuk memperoleh keadilan;

3) Memperkuat dan memaksimalkan fungsi lembaga pengadilan dalam menyelesaikan sengketa di-samping proses ajudikatif;

4) Sebagai penyempurnaan lebih lanjut SEMA No. 1 Tahun 2002 tentang Pemberdayaan Pengadilan Tingkat Pertama Menerapkan Lembaga Damai (Eks Pasal 130 HIR/154 RBg);

5) Mendorong para pihak untuk menempuh proses perdamaian yang dapat diintensifkan dengan cara mengintegrasikan proses mediasi ke dalam prosedur beperkara di Pengadilan Negeri.

b. PERMA No. 2 Tahun 2003 tidak satu ruh dengan pasal 130 HIR/154 RBg lebih bersifat memaksa, tetapi bercorak formalitas dan regulatif serta sukarena (voluntary). Hal ini disebabkan hakim dalam hukum acara perdata bersifat pasif. 
c. PERMA No. 2 Tahun 2003 merupakan salah satu bentuk peraturan pelaksanaan dari undang-undang atau biasa disebut dengan subordinate legislations yang merupakan peraturan yang didelegasikan oleh undang-undang (delegated legislations). PERMA No. 2 Tahun 2003 tidak sesuai dengan asas peraturan perundangundangan di atasnya yaitu HIR yang notabene setingkat dengan Undang-undang.

2. Saran

Suatu peraturan perundangan yang berfungsi sebagai pelaksana dari peraturan perundangan di atasnya harus sinkron dengan peraturan yang ada diatasnya. Apabila pengaturan mengenai mediasi di pengadilan dimaksudkan untuk mengesampingkan asas yang digariskan dalam HIR khususnya Pasal 130/ Pasal 154 Rbg, maka pengaturannya harus setingkat dengan undang-undanga. Sehingga dalam hal ini akan berlaku asas "Lex Spesialis Derogat Legi Generali".

\section{Daftar Pustaka}

Asshiddiqie, Jimly. 2006. Pengantar Ilmu Hukum Tata Negara. Jakarta: Sekretariat Jenderal dan Kepaniteraan Konstitusi;

Harahap, Yahya. 1997. Beberapa Tinjauan Mengenai Sistem Peradilan dan
Penyelesaian Sengketa. Jakarta: Sinar Grafika ;

IICT. Penyusun Rancangan PERMA tentang Prosedur Mediasi di Pengadilan: Sebuah Instituionalisasi Mediasi ke dalam Sistem Peradilan di Indonesia, (On-line), 05 Agustus 2003, www.unej.ac.id, (diakses 26 Februari 2006)

Legowo, Pramono Suko dan Rahadi Wasi Bintoro. 2007. Efektivitas Sistem Peradilan Sederhana Cepat dan Biaya Ringan, Purwokerto: Laporan Hasil Penelitian Sumber dana Anggaran Rutin Unsoed.

Mertokusumo, Sudikno, 2002, Hukum Acara Perdata Indonesia. Yogyakarta: Liberty;

Pusat Mediasi Nasional (PMN). Types of Mediation (on-line), 6 Juli 2004, www.pmn.or.id, (diakses 26 Februari 2006)

Ranggawidjaja, H. Rosjidi. 1998. Pengantar Ilmu Perundang-Undangan Indonesia. Bandung: CV. Mandar Maju;

Soemitro, Ronny Hanitijo, 1988, Metode Penelitian dan Jurimetri, Jakarta: Ghalia Indoneisia;

Sutantio, Retnowulan dan Iskandar Oeripkartawinata. 2002. Hukum Acara Perdata dalam Teori dan Praktek. Bandung: Mandar Maju; 